\title{
PARTISIPASI DAN PERUBAHAN KESEJAHTERAAN ANGGOTA KELOMPOK SADAR WISATA DALAM PENGELOLAAN DESA WISATA NGLANGGERAN, GUNUNGKIDUL, YOGYAKARTA
}

\author{
Participation and Changes in Welfare of Kelompok Sadar Wisata \\ Member in Nglanggeran Tourism Village Management, Gunungkidul, \\ Yogyakarta
}

\author{
Venny Kartika Manik*) dan Djuara P Lubis \\ Departemen Sains Komunikasi dan Pengembangan Masyarakat, Fakultas Ekologi Manusia, \\ Institut Pertanian Bogor, Darmaga Bogor 16680, Indonesia \\ *)E-mail: vennykartika13@gmail.com;
}

Diterima: 3-11-2020 | Disetujui: 30-08-2021 | Publikasi online: 13-09-2021

\begin{abstract}
According to the law No. 10 of 2009 on Tourism, that the state of nature, flora, and fauna, history, art, and culture owned by the Indonesian nation is a resource And the capital of tourism development for the enhancement of people's prosperity and community welfare level. The participation and support of the community is important for the sustainability and continuity of tourism village. The level of community participation can be seen starting from planning, implementing, and evaluation. The purpose of this research is to analyse the correlation between level of participation and changes in welfare member of Pokdarwis. The research method used is a quantitative approach with 50 respondents and supported by in-depth interview data to informants. The results of this research showed that there is a strong relation between type of tourism business on individual characteristic with member of Pokdarwis' participation level, there is a significant relation between member of Pokdarwis' participation with changes in welfare in terms of income levels, environmental conditions, and social conditions.
\end{abstract}

Keywords: Changes in welfare, Participation, Villaged-based tourism

\section{ABSTRAK}

Menurut Undang-undang No.10 Tahun 2009 tentang Kepariwisataan, bahwa keadaan alam, flora, dan fauna, peninggalan sejarah, seni, dan budaya yang dimiliki bangsa Indonesia merupakan sumber daya dan modal pembangunan kepariwisataan untuk peningkatan kemakmuran dan kesejahteraan rakyat. Partisipasi dan dukungan dari masyarakat merupakan hal yang penting untuk keberlangsungan dan keberlanjutan desa wisata. Tingkat partisipasi masyarakat bisa dilihat mulai dari tahap pengambilan keputusan, pelaksanaan, dan evaluasi. Tujuan dari penelitian ini adalah menganalisis hubungan antara tingkat partisipasi yang dilakukan dalam pengelolaan Desa Wisata Nglanggeran dengan perubahan kesejahteraan anggota Pokdarwis. Metode penelitian yang digunakan yaitu pendekatan kuantitatif dengan jumlah responden 50 orang dan didukung oleh data wawancara mendalam kepada informan. Hasil penelitian menunjukkan bahwa terdapat hubungan yang kuat antara jenis usaha wisata pada karakteristik individu dengan tingkat partisipasi anggota Pokdarwis, tingkat partisipasi anggota Pokdarwis memiliki hubungan yang signifikan dengan perubahan kesejahteraan dalam aspek tingkat pendapatan, kondisi lingkungan, dan kondisi sosial.

Kata Kunci: Desa wisata, Partisipasi, Perubahan kesejahteraan

Content from this work may be used under the terms of the Creative Commons Attribution-ShareAlike 4.0 International. Any further distribution of this work must maintain attribution to the author(s) and the title of the work, journal citation and DOI.

Published under Department of Communication and Community Development Science, IPB University

E-ISSN: 2442-4102 | P-ISSN: 1693-3699 



\section{PENDAHULUAN}

\section{Latar Belakang}

Sejak dikeluarkannya Undang-undang No.06 tahun 2014 tentang Desa, banyak sekali desa yang mengalami perubahan ke arah yang baik ditandai dengan terjadinya perubahan struktur ekonomi desa kontemporer (Kushandajani 2015). Undang-undang ini secara khusus menjelaskan satu dari tugas pemerintah desa yaitu desa diberi kebebasan untuk mengatur, mengurus dan memanfaatkan aset-aset desa yang berkaitan dengan sumber daya alam yang dimiliki oleh desa tersebut dengan tujuan untuk kemajuan dan kesejahteraan desa.

Pariwisata sebagai sektor industri jasa, telah memberikan kontribusi dan peran yang besar dalam pembangunan perekonomian nasional, pengembangan wilayah yang tersebar di beberapa daerah di Indonesia maupun peningkatan kesejahteraan masyarakat. Sektor pariwisata juga merupakan salah satu penyumbang devisa negara, di samping itu sektor pariwisata memiliki peran sosial, budaya dan lingkungan karena sektor pariwisata merupakan upaya pelestarian sumber daya alam dan budaya. Menurut data dari Kementerian Pariwisata jumlah devisa yang dihasilkan oleh sektor pariwisata di Indonesia setiap tahunnya meningkat. Pada tahun 2016 pendapatan dari sektor pariwisata mencapai US \$ 1.927 juta (KEMENPAR 2017). Pemerintah terus berusaha untuk menambah devisa negara melalui kegiatan pariwisata, salah satunya dengan cara meningkatkan pariwisata lokal. Pariwisata lokal merupakan potensi wilayah yang dimiliki oleh setiap daerah.

Setiap daerah yang memiliki berbagai potensi pariwisata lokal atau daerah akan dikelola serta dikembangkan untuk memenuhi kebutuhan masyarakat, baik secara ekonomi maupun non- ekonomi. Dewasa ini dikenal dengan program SDGs (Sustainable Development Goals) yaitu suatu program yang salah satu tujuan dari programnya yaitu mengurangi kemiskinan dengan menjaga keseimbangan tiga dimensi pembangunan berkelanjutan yaitu lingkungan, sosial, dan ekonomi. Pada sektor pariwisata diwujudkan dengan memberdayakan masyarakat mulai dari merumuskan konsep program wisata yang akan ditawarkan, memberdayakan masyarakat lokal sebagai tenaga kerja secara langsung maupun tidak langsung, dan memasarkan program yang sudah disiapkan dengan persiapan yang matang dengan menggunakan sistem bottom-up. Program ini diharapkan dapat berkelanjutan sehingga mampu membawa masyarakat desa ke arah kehidupan yang lebih baik dan sejahtera dari sebelumnya.

Kesejahteraan dilihat berdasarkan BPS (2010) yakni; (1) tingkat pendapatan; (2) tingkat konsumsi atau pengeluaran; (3) tingkat keadaan tempat tinggal; (4) tingkat fasilitas tempat tinggal; (5) tingkat kesehatan; (6) tingkat kemudahan mendapatkan pelayanan kesehatan; (7) tingkat kemudahan mendapatkan pendidikan; (8) tingkat kemudahan mendapatkan fasilitas transportasi. Pada Undangundang No. 11 Tahun 2009 tentang kesejahteraan masyarakat, dijelaskan bahwa kesejahteraan masyarakat adalah kondisi di mana masyarakat dapat memenuhi kebutuhan material, spiritual, dan sosial warga negara agar dapat hidup layak dan mampu mengembangkan diri, sehingga dapat melaksanakan fungsi sosialnya.

Dalam rangka mencapai desa wisata yang berkelanjutan dibutuhkan partisipasi aktif dari masyarakat desa wisata karena masyarakat memegang peran penting dalam pengembangan potensi wisata. Partisipasi dari masyarakat dalam mengelola desa wisata akan menentukan bagaimana pengembangan desa wisata ini. Peran masyarakat dapat menentukan keberhasilan pengembangan desa wisata. Jika adanya partisipasi aktif dan masyarakat mendukung pengelolaan desa wisata, maka diharapkan dengan adanya desa wisata, desa wisata ini dapat bermanfaat bagi masyarakat dalam meningkatkan kesejahteraan masyarakat yang turut serta dalam pengelolaan desa wisata. Nasdian (2014) mendefinisikan partisipasi sebagai proses aktif yang dilakukan individu, masyarakat atau kelompok untuk menentukan sesuatu, dibimbing oleh cara berpikir sendiri, serta dapat menegaskan kontrol secara efektif.

Cohen dan Uphoff (1979) mengungkapkan bahwa peran atau partisipasi yang dilakukan oleh masyarakat bisa dilihat mulai dari tahap perencanaan, pelaksanaan, pengelolaan atau pemanfaatan, pengawasan, menikmati hasil dan evaluasi. Penting untuk diketahui bahwa dalam penerapannya partisipasi masyarakat tidak lepas dari pengaruh faktor-faktor yang memengaruhi individu/masyarakat dalam berpartisipasi. 
Desa Wisata Nglanggeran yang berlokasi di Kecamatan Patuk, Kabupaten Gunungkidul, D.I. Yogyakarta, Provinsi Jawa Tengah dikelola oleh Kelompok Sadar Wisata (Pokdarwis) Desa Nglanggeran. Desa Wisata Nglanggeran menawarkan keindahan alam Kawasan Ekowisata Gunung Api Purba dan Embung Nglanggeran. Selain itu, terdapat juga atraksi wisata yang ditawarkan berupa kegiatan perkemahan, kegiatan malam keakraban, outbond, kegiatan live in, flying fox, wisata budaya seni tari, dan seni karawitan. Banyaknya atraksi yang ditawarkan di Desa Wisata Nglanggeran membuat pengunjung selalu meningkat setiap tahun. Keberadaan destinasi wisata merupakan peluang bagi masyarakat untuk meningkatkan kesejahteraan individu/masyarakat yang terlibat dalam pengelolaan desa wisata. Menariknya, Desa Wisata Nglanggeran sudah mendapatkan berbagai penghargaan seperti ISTA (Indonesia Sustainable Tourism Award) pada tahun 2017, ASTA (ASEAN Sustainable Tourism Award) pada tahun 2018.

Masalah penelitian berdasarkan hal di atas dapat dirumuskan sebagai berikut: (1) Bagaimana partisipasi anggota Kelompok Sadar Wisata dalam pengelolaan Desa Wisata Nglanggeran? (2) Bagaimana hubungan karakteristik individu dan layanan Kelompok Sadar Wisata dengan partisipasi yang dilakukan anggota Kelompok Sadar Wisata dalam pengelolaan Desa Wisata Nglanggeran? (3) Bagaimana hubungan partisipasi dalam pengelolaan desa wisata dengan perubahan kesejahteraan anggota Kelompok Sadar Wisata Desa Wisata Nglanggeran?

\section{PENDEKATAN LAPANGAN}

\section{Metode Penelitian}

Penelitian ini menggunakan pendekatan kuantitatif dengan metode survei menggunakan kuesioner. Data kualitatif dikumpulkan dengan metode wawancara mendalam (in depth interview) kepada informan yang datanya digunakan untuk mendukung data yang telah didapatkan dari pendekatan kuantitatif.

\section{Lokasi dan Waktu Penelitian}

Penelitian ini dilakukan di Desa Wisata Nglanggeran, Kecamatan Patuk, Kabupaten Gunungkidul, D.I. Yogyakarta. Pemilihan lokasi dilakukan secara sengaja (purposive) dengan alasan Desa Wisata Nglanggeran merupakan salah satu Desa Wisata terbaik ASEAN pada tahun 2017, Desa Wisata Nglanggeran juga sudah menerima beberapa penghargaan seperti ISTA (Indonesia Sustainable Tourism Award) pada tahun 2017, ASTA (ASEAN Sustainable Tourism Award) pada tahun 2018. Desa Wisata Nglanggeran ini juga menarik untuk diteliti karena kesejahteraan masyarakat meningkat dan merupakan Desa Wisata yang tetap menjaga kelestarian budaya dan keasrian Sumber Daya Alamnya. Waktu penelitian dilaksanakan pada bulan Desember 2019 hingga Juli 2020 dan pengambilan data dilakukan pada bulan Februari - Maret 2020.

\section{Teknik Penentuan Informan dan Responden}

Subjek yang diambil sebagai sumber data di dalam penelitian ini adalah responden dan informan. Responden adalah seseorang atau individu yang dapat memberikan informasi mengenai dirinya sendiri terkait partisipasinya dalam pengelolaan Desa Wisata Nglanggeran serta perubahan tingkat kesejahteraan akibat pengembangan Desa Wisata Nglanggeran. Unit analisis dalam penelitian ini adalah anggota Pokdarwis Nglanggeran. Populasi penelitian ini adalah 134 anggota Pokdarwis dan dari populasi tersebut diambil 50 responden dengan teknik pengambilan sampel clustered random sampling, yaitu dengan mengelompokkan responden sesuai dengan jenis usaha wisata yang dilakukan dalam pengelolaan Desa Wisata Nglanggeran. Adapun penggolongannya, yaitu penyedia homestay, pemandu wisata, pembuat suvenir, petugas kebersihan, dan tukang parkir. Dari kelima jenis usaha wisata tersebut, setiap responden diambil sesuai proporsi dari masing-masing cluster berdasarkan data temuan di lapang.

Informan dalam penelitian ini adalah orang yang dapat memberikan keterangan mengenai informasi secara benar dan lengkap yang berkaitan dengan penelitian dan sebagai pelengkap atau mendukung topik yang diteliti, seperti pengurus Pokdarwis Nglanggeran dan Kepala Desa Nglanggeran. Pemilihan terhadap informan dilakukan secara sengaja (purposive). 


\section{Teknik Pengolahan dan Analisis Data}

Penelitian ini mempunyai dua jenis data yang diolah dan dianalisis yaitu data kuantitatif dan data kualitatif. Data yang diperoleh secara kuantitatif melalui kuesioner diolah melalui Microsoft Excel 2010 yang kemudian akan diolah dalam aplikasi SPSS Version 20.0. Data akan dianalisis dengan menggunakan tabel frekuensi untuk melihat data awal responden pada masing-masing variabel secara tunggal dan menggunakan tabulasi silang. Kemudian data kuantitatif diolah menggunakan uji korelasi Rank Spearman aplikasi SPSS Statistics Version 21.0 untuk menganalisis ada atau tidaknya hubungan antar variabel serta bagaimana arah hubungan antara kedua variabel tersebut. Pada penelitian ini, variabel yang akan diuji yaitu karakteristik individu dan layanan Pokdarwis dengan tingkat partisipasi, serta tingkat partisipasi dengan perubahan kesejahteraan anggota Pokdarwis. Penentuan layanan Pokdarwis, tingkat partisipasi, dan perubahan kesejahteraan diperhitungkan melalui skala likert dan standar deviasi dengan diakhiri menggunakan skor rataan di mana setiap jawaban dari pertanyaan yang diberikan kepada responden diberikan bobot penilaian dan mengklasifikasikannya rendah, sedang, atau tinggi. Sedangkan untuk karakteristik individu diolah berdasarkan definisi operasional yang telah dibuat.

Data kualitatif diperlukan untuk mendukung data kuantitatif yang diperoleh. Data kualitatif diperoleh dari wawancara mendalam dengan informan melalui pertanyaan terstruktur. Data kualitatif dianalis melalui tiga tahap yaitu reduksi data, penyajian data, dan verifikasi.

\section{GAMBARAN UMUM LOKASI PENELITIAN}

\section{Keadaan Geografis dan Demografi}

Desa Nglanggeran berada di Kecamatan Patuk, Kabupaten Gunungkidul, Provinsi D.I. Yogyakarta, mempunyai luas wilayah 762,8 hektar. Desa Nglanggeran terbagi ke dalam 5 pedukuhan, yaitu Dukuh Karangsari, Dukuh Doga, Dukuh Nglanggeran Kulon, Dukuh Nglanggeran Wetan, dan Dukuh Gunung Butak. Desa Nglanggeran terbagi menjadi beberapa tipologi, yaitu persawahan, perkebunan, peternakan, kerajinan dan industri kecil. Berdasarkan data desa pada bulan November 2019, dilihat dari kepadatan penduduk yaitu sebesar 349,24jiwa per kilo meter. Jumlah penduduk Desa Nglanggeran sebanyak 2.664 jiwa terdiri dari 1.328 jiwa laki-laki dan 1.336 jiwa perempuan serta jumlah Kepala Keluarga (KK) sebanyak 837 KK.

\section{Profil Desa Wisata Nglanggeran}

Desa Wisata Nglanggeran merupakan desa wisata yang terletak di Kabupaten Gunungkidul, Daerah Istimewa Yogyakarta. Kabupaten Gunungkidul yang terkenal akan keindahan wisata pantainya, namun Desa Wisata Nglanggeran memiliki keunikan tersendiri. Desa Wisata Nglanggeran memiliki keunikan potensi wisata yaitu terdapatnya ekowisata Gunung Api Purba Nglanggeran, Embung Nglanggeran, dan Air Terjun Kedungkandang. Desa Wisata Nglanggeran menerapkan prinsip konservasi dan sangat menjaga keasrian alamnya. Desa Wisata Nglanggeran juga mengimplementasikan 7 prinsip sapta pesona (aman, tertib, bersih, sejuk, indah, ramah, dan kenangan) dalam kehidupannya sehari- hari.

Desa Wisata Nglanggeran dikelola oleh Kelompok Sadar Wisata (POKDARWIS) Nglanggeran. Pada tahun 1999, Desa Wisata Nglanggeran dikelola oleh karang taruna yaitu Karang Taruna Purba Mandiri, maka pada saat ini sebagian anggota Pokdarwis Nglanggeran merupakan anggota karang taruna. Pada tahun 2007, sesuai peraturan dari pemerintah pusat mengharuskan dibentuknya Badan Pengelola Desa Wisata untuk pengelola kawasan wisata. Dan pada tahun 2008, Badan Pengelola Desa Wisata Nglanggeran berubah nama menjadi Kelompok Sadar Wisata (POKDARWIS) Nglanggeran agar sesuai dengan perundang-undangan oleh Kementerian Pariwisata Republik Indonesia. 


\section{HASIL DAN PEMBAHASAN}

\section{Karakteristik Kelompok Sadar Wisata (POKDARWIS) Nglanggeran}

Umur responden berada pada rentang usia 18 tahun hingga 69 tahun. Anggota Pokdarwis Nglanggeran termuda yakni berusia 18 tahun, sementara usia tertua berada dalam usia 69 tahun. Mayoritas umur responden dalam penelitian ini merupakan individu yang termasuk dalam kategori dewasa pertengahan (30 sampai 50 tahun), yaitu sebanyak 27orang atau sebesar 54 persen dari keseluruhan responden. Hal ini disebabkan karena anggota Pokdarwis Nglanggeran secara keseluruhan termasuk ke dalam kategori umur dewasa pertengahan. Anak muda di Desa Wisata Nglanggeran cenderung merantau ke luar kota untuk mencari pekerjaan lain, sementara untuk kategori dewasa akhir banyak yang memilih untuk mengelola lahan pertanian dan usaha yang mereka miliki.

Tingkat pendidikan responden terendah yaitu tamatan Sekolah Dasar (SD), sementara tingkat pendidikan tertinggi merupakan tamatan Diploma (D3). Mayoritas tingkat pendidikan responden dalam penelitian ini merupakan individu yang termasuk dalam kategori pendidikan sedang (SMP/MTs/Seederajat) yaitu sebanyak 23 orang atau sebesar 46 persen. Terdapat 7 orang atau sebesar 14 persen yang merupakan tamatan SD dan 20 orang atau sebesar 40 persen yang melanjutkan pendidikan ke jenjang yang lebih tinggi yaitu (SMA dan $\geq$ Diploma) dan hanya 1 orang responden yang melanjutkan pendidikan ke jenjang Diploma (D3).

Masyarakat yang mengelola pariwisata di Desa Nglanggeran merupakan masyarakat yang merupakan penduduk asli desa tersebut dan telah menetap sejak mereka lahir, mereka melihat potensi yang ada di desa tersebut lalu kemudian memanfaatkannya sehingga menjadi lapangan pekerjaan baru bagi masyarakat desa. Responden pada penelitian ini hampir semua merupakan penduduk asli Desa Nglanggeran yang telah tinggal dan menetap lama di desa tersebut, dari sejak lahir hingga saat diwawancarai sehingga mereka mengetahui seluk beluk Desa Nglanggeran, sehingga termasuk ke dalam kategori sangat lama. Namun terdapat 1 orang responden yang termasuk dalam kategori lama tinggal lama, karena beliau bukan penduduk asli Desa Nglanggeran, beliau masih 10 tahun tinggal di Desa Nglanggeran untuk mengikuti suami yang tinggal di Desa Nglanggeran.

Indikator jumlah anggota keluarga, 19 responden pada penelitian ini termasuk dalam kategori jumlah anggota keluarga sedikit atau sebesar 38 persen, 30 orang responden termasuk dalam kategori jumlah anggota keluarga sedang atau sebesar 60 persen, dan 1 orang responden termasuk dalam kategori jumlah anggota keluarga banyak atau sebesar 2 persen.

Pada penelitian ini menggunakan metode clustered random sampling, sehingga responden dalam penelitian ini dibagi menjadi 5 jenis usaha wisata yang dilakukan di Desa Wisata Nglanggeran, yaitu penyedia homestay, pemandu wisata, pembuat suvenir, petugas kebersihan, dan tukang parker. Ke 5 kategori jenis usaha wisata tersebut didata terlebih dahulu jumlahnya, agar responden penelitian ini sesuai dengan proporsi dari populasi yang ada. Sehingga didapat jumlah responden per kategori jenis usaha wisata sesuai dengan proporsi populasi yang sudah terlampir pada tabel 1 . Walaupun responden sudah bekerja di sektor pariwisata, mayoritas responden juga memiliki pekerjaan tambahan seperti bertani, buruh harian lepas, dan supir. 
Tabel 1 Jumlah dan persentase responden berdasarkan karakteristik individu di Desa Wisata Nglanggeran 2020

\begin{tabular}{|c|c|c|c|}
\hline $\begin{array}{l}\text { Karakteristik } \\
\text { Individu }\end{array}$ & Kategori & Jumlah & Persentase \\
\hline \multirow{3}{*}{ Umur } & Dewasa Awal ( 18-29 tahun) & 16 & 32,0 \\
\hline & $\begin{array}{l}\text { Dewasa Pertengahan ( } 30-50 \\
\text { tahun) }\end{array}$ & 27 & 54,0 \\
\hline & Dewasa Akhir ( > 50 tahun) & 7 & 14,0 \\
\hline \multirow[t]{3}{*}{$\begin{array}{l}\text { Tingkat } \\
\text { Pendidikan }\end{array}$} & $\begin{array}{l}\text { Pendidikan Rendah (Tidak } \\
\text { sekolah/TK/SD) }\end{array}$ & 7 & 14,0 \\
\hline & $\begin{array}{l}\text { Pendidikan Sedang } \\
\text { (SMP/MTs/Sederajat) }\end{array}$ & 23 & 46,0 \\
\hline & $\begin{array}{l}\text { Pendidikan Tinggi ( SMA dan } \\
\geq \text { Diploma) }\end{array}$ & 20 & 40,0 \\
\hline \multirow[t]{3}{*}{ Lama Tinggal } & Sebentar $(<5$ tahun $)$ & 0 & 0 \\
\hline & Lama (5-10 tahun) & 1 & 2,0 \\
\hline & Sangat Lama ( $>10$ tahun $)$ & 49 & 98,0 \\
\hline \multirow{3}{*}{$\begin{array}{l}\text { Jumlah Anggota } \\
\text { Keluarga }\end{array}$} & Sedikit (1-3 orang) & 19 & 38,0 \\
\hline & Sedang (4-6 orang) & 30 & 60,0 \\
\hline & Banyak ( $>6$ orang) & 1 & 2,0 \\
\hline Jenis Usaha & Penyedia Homestay & 8 & 16,0 \\
\hline \multirow[t]{4}{*}{ Wisata } & Pemandu Wisata & 18 & 36,0 \\
\hline & Pembuat Suvenir & 4 & 8,0 \\
\hline & Petugas Kebersihan & 4 & 8,0 \\
\hline & Tukang Parkir & 16 & 32,0 \\
\hline Total & & 50 & 100,0 \\
\hline
\end{tabular}

\section{Layanan Kelompok Sadar Wisata}

Peranan fasilitatif pengurus Pokdarwis Nglanggeran, 84 persen responden beranggapan bahwa pengurus Pokdarwis Nglanggeran cukup berperan dalam meningkatkan partisipasi masyarakat di pengembangan desa wisata. Peran pengurus Pokdarwis Nglanggeran dinilai cukup baik dalam mengajak serta responden untuk ikut serta di kegiatan pariwisata, namun responden masih menganggap bahwa saat mengadakan rapat semua anggota Pokdarwis Nglanggeran belum seluruhnya diajak aktif untuk memberi gagasan berupa ide atau saran untuk desa wisata.

Pada peranan mendidik pengurus Pokdarwis Nglanggeran, 90 persen responden beranggapan bahwa pengurus Pokdarwis Nglanggeran cukup berperan dalam meningkatkan partisipasi masyarakat di pengembangan desa wisata. Peran pengurus Pokdarwis Nglanggeran dinilai cukup baik dalam memberikan pelatihan-pelatihan yang dibutuhkan anggota Pokdarwis, pengurus Pokdarwis juga sudah cukup baik dalam memberikan informasi dan ide terkait pengelolaan desa wisata. Namun, beberapa responden mengatakan bahwa terdapatnya anggota yang malas atau tidak bisa mengikuti pelatihan yang dibuat oleh pengurus Pokdarwis karena jadwalnya bertabrakan dengan kegiatan di luar kegiatan desa wisata. 


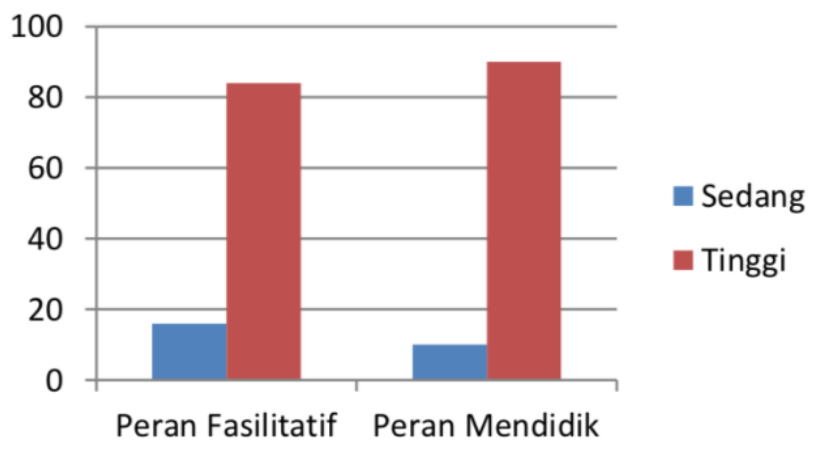

Gambar 1 Persentase anggota Pokdarwis Nglanggeran berdasarkan peran fasilitatif dan peran mendidik tahun 2020

\section{PARTISIPASI ANGGOTA KELOMPOK SADAR WISATA DALAM PENGELOLAAN DESA WISATA NGLANGGERAN}

Tingkat partisipasi anggota Pokdarwis sudah tersebar merata pada setiap kategorinya. Tingkat partisipasi responden anggota Pokdarwis Nglanggeran berada pada kategori rendah karena mayoritas responden anggota Pokdarwis Nglanggeran pada tahap pelaksanaan yang tinggi dari hasil rangkaian kegiatan yang dilakukan pada pengelolaan Desa Wisata Nglanggeran, tetapi memang pada saat rapat perencanaan dan evaluasi atau mengawasi berjalannya pengelolaan Desa Wisata Nglanggeran sebagian responden kurang aktif.

\section{Tingkat Partisipasi pada Tahap Pengambilan Keputusan}

Berdasarkan Gambar 2 tingkat partisipasi tahap pengambilan keputusan responden anggota Pokdarwis Nglanggeran berada pada kategori sedang, karena responden anggota Pokdarwis Nglanggeran mayoritas berada pada kategori sedang sebanyak 20 orang atau 40,0 persen. Sedangkan untuk kategori rendah sebanyak 15 orang atau 30,0 persen, dan untuk jumlah responden pada kategori tinggi sebanyak 15 orang atau 30,0 persen. Menurut hasil wawancara di lapang, tingkat partisipasi tahap perencanaan hasilnya tersebar merata pada setiap kategorinya. Mayoritas responden berada pada kategori sedang dikarenakan pada saat rapat perencanaan anggota Pokdarwis Nglanggeran ikut hadir namun tidak aktif bertanya dan mengeluarkan pendapat.

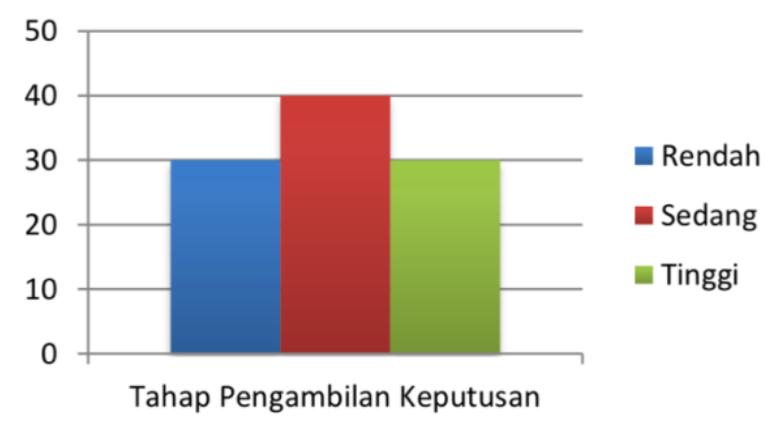

Gambar 2 Persentase responden anggota Pokdarwis Nglanggeran berdasarkan tingkat partisipasi dalam tahap pengambilan keputusan tahun 2020

\section{Tingkat Partisipasi pada Tahap Pelaksanaan}

Pada Gambar 3 tingkat partisipasi tahap pelaksanaan responden anggota Pokdarwis Nglanggeran berada pada kategori sedang, karena responden anggota Pokdarwis Nglanggeran mayoritas berada pada kategori sedang sebanyak 25 orang atau 50,0 persen. Sedangkan untuk kategori rendah sebanyak 1 orang atau 2,0 persen, dan untuk jumlah responden pada kategori tinggi sebanyak 24 orang atau 48,0 persen. Menurut hasil wawancara di lapang, tingkat partisipasi pada tahap pelaksanaan mayoritas responden yakni anggota Pokdarwis Nglanggeran sudah cukup antusias dan banyak responden yang 
mengaku sangat senang terlibat dalam pengelolaan Desa Wisata Nglanggeran, karena mereka sangat senang desa mereka dapat dikenal oleh masyarakat Indonesia secara luas.

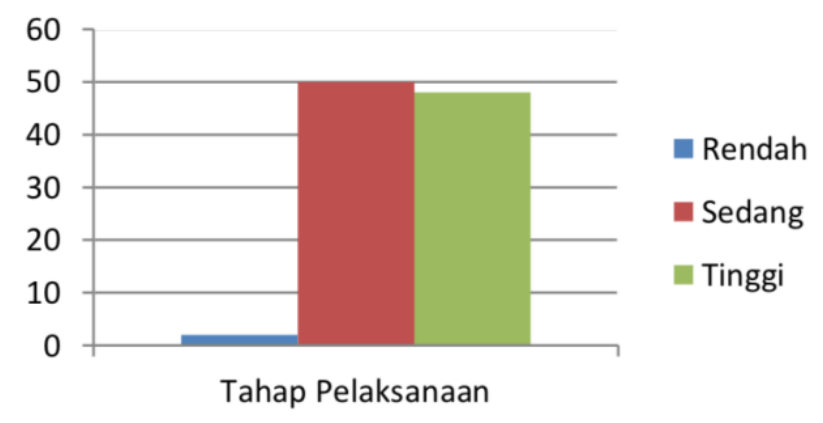

Gambar 3 Persentase responden anggota Pokdarwis Nglanggeran berdasarkan tingkat partisipasi dalam tahap pelaksanaan tahun 2020

\section{Tingkat Partisipasi pada Tahap Evaluasi}

Gambar 4 menunjukkan bahwa tingkat partisipasi tahap evaluasi responden anggota Pokdarwis Nglanggeran berada pada kategori rendah, karena responden anggota Pokdarwis Nglanggeran mayoritas berada pada kategori rendah sebanyak 24 orang atau 48,0 persen. Sedangkan untuk kategori sedang sebanyak 14 orang atau 28,0 persen, dan untuk jumlah responden pada kategori tinggi sebanyak 12 orang atau 24,0 persen. Menurut hasil wawancara di lapang, tingkat partisipasi pada tahap evaluasi mayoritas responden yakni anggota Pokdarwis Nglanggeran mengatakan bahwa mereka cenderung hanya menerima hasil penilaian atau evaluasi yang disampaikan oleh pengurus Pokdarwis Nglanggeran terkait kegiatan pengelolaan desa wisata saat rapat evaluasi.

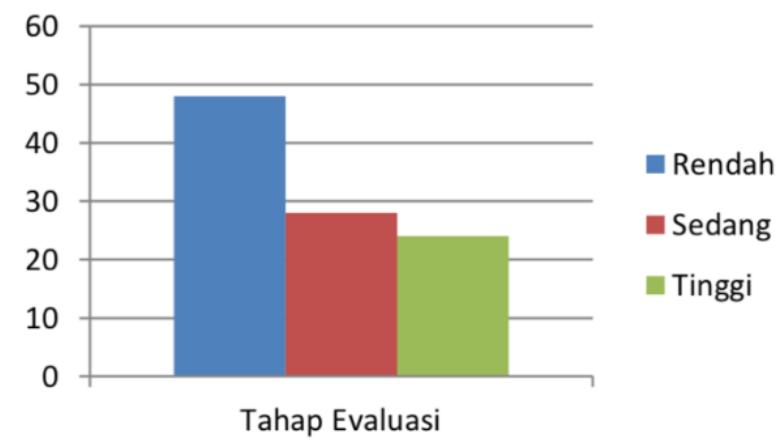

Gambar 4 Persentase responden anggota Pokdarwis Nglanggeran berdasarkan tingkat partisipasi dalam tahap evaluasi tahun 2020

\section{Hubungan antara Karakteristik Individu dengan Tingkat Partisipasi}

Pada indikator umur, uji korelasi menunjukkan terdapat hubungan yang tidak signifikan antara umur dengan tingkat partisipasi anggota, karena nilai $\alpha 0,260$ yang lebih besar dari 0,05 . Hasil uji korelasi Rank Spearman menunjukkan nilai koefisien korelasi sebesar 0,162 yang berarti nilai tersebut menunjukkan hubungan yang sangat lemah. Hal tersebut dikarenakan responden yang termasuk dalam kategori dewasa akhir mulai tidak rutin untuk menghadiri rapat, menyatakan pendapat, memberikan solusi, serta mengikuti kegiatan pelatihan-pelatihan yang mendukung pengelolaan desa wisata. Pada kategori usia tersebut, responden beranggapan bahwa anggota- anggota yang usianya lebih muda sudah cukup mewakili mereka terutama dalam kegiatan rapat, selain itu mereka juga mempunyai pengetahuan dan pengalaman yang banyak, sehingga responden lebih bisa berpendapat, memberikan solusi, dan ide yang baik untuk kebaikan pengelolaan Desa Wisata Nglanggeran. 
Uji korelasi antara tingkat pendidikan dengan tingkat partisipasi anggota menunjukkan hubungan yang tidak signifikan, dikarenakan nilai $\alpha$ 0,245 yang lebih besar dari 0,05. Kemudian berdasarkan hasil uji korelasi Rank Spearman, nilai koefisien korelasi sebesar 0,167 yang berarti nilai tersebut menunjukkan hubungan yang sangat lemah. Hasil uji tersebut didukung oleh fakta di lapangan, bahwa mayoritas anggota dari Pokdarwis merupakan tamatan SMP. Juga tidak terdapatnya standar tingkat pendidikan orang yang ingin menjadi anggota Pokdarwis Nglanggeran, sehingga tidak menutup kemungkinan siapapun dapat bergabung menjadi anggota Pokdarwis. Hasil wawancara di lapang, terdapat responden dengan tingkat pendidikan rendah yang memiliki tingkat partisipasi rendah karena merasa malu dan tidak layak.

Indikator lama tinggal, uji korelasi antara lama tinggal dengan tingkat partisipasi anggota menunjukkan hubungan yang tidak signifikan, dikarenakan nilai $\alpha 0,573$ yang lebih besar dari 0,05 . Kemudian berdasarkan hasil uji korelasi Rank Spearman, nilai koefisien korelasi sebesar -0,082 yang berarti nilai tersebut menunjukkan hubungan yang berlawanan, karena nilai korelasinya negatif. Responden yang sudah lama tinggal di desa tersebut bahkan lahir di desa tersebut belum tentu memiliki partisipasi yang tinggi dalam pengelolaan desa wisata. Namun terdapat responden yang termasuk dalam kategori lama tinggal sedang merasa sangat bersyukur dengan adanya pengelolaan desa wisata ini.

Uji korelasi antara jumlah anggota keluarga dengan tingkat partisipasi anggota menunjukkan hubungan yang tidak signifikan, dikarenakan nilai $\alpha 0,081$ yang lebih besar dari 0,05 . Kemudian berdasarkan hasil uji korelasi Rank Spearman, nilai koefisien korelasi sebesar 0,249 yang berarti nilai tersebut menunjukkan hubungan yang sangat lemah. Hasil uji tersebut didukung oleh fakta di lapangan, bahwa mayoritas responden termasuk dalam kategori jumlah anggota keluarga sedang memiliki tingkat partisipasi yang rendah dalam pengelolaan desa wisata.

Karakteristik anggota berupa jenis usaha wisata yang dijalani dalam pengelolaan desa wisata, memiliki hubungan yang signifikan dengan tingkat partisipasi anggota. Hal tersebut dikarenakan nilai $\alpha 0.000$ lebih kecil dari 0.05 . Selain itu, nilai korelasi yang dihasilkan yaitu sebesar $0.823 * *$ yang berada pada rentang 0.76-0.99 yang berarti bahwa hubungan yang terjadi antar dua variabel memiliki hubungan yang sangat kuat. Hal ini dikarenakan jenis usaha wisata yang dijalani oleh responden berhubungan erat dengan keterlibatannya dalam pengelolaan Desa Wisata Nglanggeran. Menurut fakta lapang, beberapa jenis usaha wisata seperti pembuat suvenir dan petugas kebersihan cenderung memiliki tingkat partisipasi yang rendah karena mereka menganggap tingkat kepentingannya rendah saat datang untuk mengikuti rapat.

\section{Hubungan antara Layanan Kelompok Sadar Wisata dengan Tingkat Partisipasi Anggota Pokdarwis}

Penilaian responden terhadap peran fasilitatif pengurus Pokdarwis dengan tingkat partisipasi anggota responden memiliki hubungan yang tidak signifikan, karena nilai $\alpha 0,318$ yang lebih besar dari 0,05 . Hasil uji korelasi Rank Spearman menunjukkan nilai koefisien korelasi sebesar -0,144 yang berarti bahwa hubungan yang terjadi antar dua variabel memiliki hubungan yang berlawanan karena nilai korelasinya negatif. Terbukti bahwa jika responden memiliki penilaian yang sedang terhadap peran memfasilitasi pengurus Pokdarwis, maka tingkat partisipasi responden dalam pengelolaan Desa Wisata Nglanggeran terasuk dalam kategori rendah.

Penilaian responden terhadap peran mendidik pengurus Pokdarwis dengan tingkat partisipasi anggota responden memiliki hubungan yang kurang signifikan, karena nilai $\alpha 0,107$ yang lebih besar dari 0,05. Hasil uji korelasi Rank Spearman menunjukkan nilai koefisien korelasi sebesar -0,231 yang berarti bahwa hubungan yang terjadi antar dua variabel memiliki hubungan yang berlawanan karena nilai korelasinya negatif. Terbukti bahwa jika responden memiliki penilaian yang sedang terhadap peran mendidik pengurus Pokdarwis, maka tingkat partisipasi responden dalam pengelolaan Desa Wisata Nglanggeran terasuk dalam kategori rendah. 


\section{PERUBAHAN KESEJAHTERAAN ANGGOTA POKDARWIS DALAM PENGELOLAAN DESA WISATA NGLANGGERAN}

\section{Perubahan Kesejahteraan}

Perubahan kesejahteraan anggota Pokdarwis Nglanggeran memiliki sebaran yang merata, namun berada pada kategori rendah. Hal tersebut dibuktikan oleh mayoritas berada pada kategori rendah sebanyak 21 orang atau 42,0 persen pada perubahan tingkat pendapatan dan 19 orang atau 38,0 persen pada perubahan kondisi lingkungan. Sedangkan untuk kondisi sosial berada pada kategori sedang sebanyak 19 orang atau 38,0 persen. Berdasarkan data di lapang, perekonomian masyarakat Desa Wisata Nglanggeran masih tergolong rendah. Perubahan tingkat pendapatan yang dirasakan oleh anggota Pokdarwis Nglanggeran berada pada kategori tinggi sebesar 34,0 persen sedangkan pada kategori rendah sebesar 42,0 persen. Hal ini disebabkan beberapa responden merasa bahwa perubahan tingkat pendapatan sebelum dan sesudah terlibat dalam pengelolaan desa wisata belum jelas terlihat.

Perubahan kondisi lingkungan yang dirasakan oleh anggota Pokdarwis Nglanggeran berada pada kategori tinggi sebesar 34,0 persen sedangkan pada kategori sedang sebesar 38,0 persen. Berdasar hasil wawancara di lapang, perubahan kondisi lingkungan sudah sangat dirasakan warga Desa Nglanggeran khususnya anggota Pokdarwis Nglanggeran. Perubahan yang sudah dirasakan seperti, sudah adanya pengelolaan sampah oleh BUMDES, tata wilayah yang membuat lingkungan lebih asri, hijau, dan lebih indah dipandang mata. Juga perilaku dan kesadaran untuk menjaga lingkungan semakin bertumbuh.

Perubahan kondisi sosial yang dirasakan oleh anggota Pokdarwis Nglanggeran berada pada kategori tinggi sebesar 28,0 persen sedangkan pada kategori rendah sebesar 38,0 persen. Menurut penuturan beberapa responden kondisi ini disebabkan oleh kondisi sosial masyarakat desa pada umumnya sudah baik, sejak dulu sudah menerapkan perilaku tolong-menolong, juga sudah akrab antara satu sama lain. Namun, mayoritas responden merasakan perubahan tingkat kepercayaan diri untuk berinteraksi dengan orang lain.

\section{Hubungan antara Tingkat Partisipasi dengan Perubahan Kesejahteraan}

Tingkat partisipasi yang dilakukan anggota Pokdarwis Nglanggeran memiliki hubungan yang signifikan dengan perubahan tingkat pendapatan anggota. Uji korelasi menunjukkan terdapat hubungan yang signifikan antara tingkat partisipasi yang dilakukan dengan perubahan tingkat pendapatan responden, karena nilai $\alpha 0,000$ yang lebih kecil dari 0,05. Hasil uji korelasi Rank Spearman menunjukkan nilai koefisien korelasi sebesar $0,679 * *$ yang berarti bahwa hubungan yang terjadi antar dua variabel memiliki hubungan yang kuat. Terbukti bahwa jika responden memiliki tingkat partisipasi dalam pengelolaan Desa Wisata Nglanggeran tinggi, maka perubahan tingkat pendapatan responden pun akan tinggi. Perubahan pada tingkat pendapatan, yaitu jumlah pendapatan, pemenuhan kebutuhan, tingkat pengangguran, dan kesempatan kerja sebelum dan sesudah adanya pengelolaan Desa Wisata Nglanggeran. Mayoritas responden mengaku bahwa perubahan tingkat pendapatan yang dirasakan khususnya untuk anggota Pokdarwis Nglanggeran sangat terasa sebelum dan sesudah adanya pengelolaan Desa Wisata Nglanggeran.

Tingkat partisipasi yang dilakukan anggota Pokdarwis Nglanggeran memiliki hubungan yang signifikan juga dengan perubahan kondisi lingkungan yang dirasakan oleh anggota Pokdarwis. Uji korelasi menunjukkan terdapat hubungan yang signifikan antara tingkat partisipasi yang dilakukan dengan perubahan kondisi lingkungan yang dirasakan oleh responden, karena nilai $\alpha 0,000$ yang lebih kecil dari 0,05. Hasil uji korelasi Rank Spearman menunjukkan nilai koefisien korelasi sebesar $0,561 * *$ yang berarti bahwa hubungan yang terjadi antar dua variabel memiliki hubungan yang kuat. Terbukti bahwa jika responden memiliki tingkat partisipasi dalam pengelolaan Desa Wisata Nglanggeran tinggi, maka perubahan kondisi lingkungan yang dirasakan oleh responden dalam pun akan tinggi. Perubahan pada kondisi lingkungan, yaitu kebersihan lingkungan, keasrian lingkungan, sistem pengelolaan sampah, dan kelestarian alam sebelum dan sesudah adanya pengelolaan Desa 
Wisata Nglanggeran. Saat wawancara di lapang, beberapa di antara responden sangat merasakan perbedaan kondisi lingkungan sebelum dan sesudah adanya pengelolaan desa wisata.

Tingkat partisipasi yang dilakukan anggota Pokdarwis Nglanggeran memiliki hubungan yang signifikan dengan perubahan kondisi sosial yang dirasakan oleh anggota Pokdarwis. Uji korelasi menunjukkan terdapat hubungan yang signifikan antara tingkat partisipasi yang dilakukan dengan perubahan kondisi sosial yang dirasakan oleh responden, karena nilai $\alpha 0,001$ yang lebih kecil dari 0,05. Hasil uji korelasi Rank Spearman menunjukkan nilai koefisien korelasi sebesar 0,439** yang berarti bahwa hubungan yang terjadi antar dua variabel memiliki hubungan yang cukup. Terbukti bahwa jika responden memiliki tingkat partisipasi dalam pengelolaan Desa Wisata Nglanggeran rendah, maka perubahan kondisi sosial yang dirasakan oleh responden dalam pun akan rendah. Pada perubahan kondisi sosial, yaitu bagaimana keakraban masyarakat desa, kepekaan atau kepedulian, tingkat kepercayaan diri untuk berinteraksi dengan wisatawan, perilaku tolong- menolong, dan upaya melestarikan nilai-nilai lokal sebelum dan sesudah adanya pengelolaan Desa Wisata Nglanggeran. Hasil data di lapang bahwa sebagian dari responden merasa kondisi sosial masyarakat desa sudah baik, namun setelah adanya pengelolaan desa wisata terjadinya perubahan ataupun peningkatan kondisi sosial.

\section{PENUTUP}

\section{Kesimpulan}

Berdasarkan hasil penelitian maka didapatkan kesimpulan sebagai berikut: (1) Tingkat partisipasi anggota Pokdarwis Nglanggeran secara formal dalam pengelolaan Desa Wisata Nglanggeran pada umumnya cenderung merata yaitu berada pada kategori sedang. Tingkat partisipasi masyarakat pada tahap pengambilan keputusan dan tahap pelaksanaan berada pada kategori sedang, sedangkan tahap evaluasi berada pada kategori rendah. Hal ini menunjukkan bahwa anggota Pokdarwis belum sepenuhnya terlibat secara aktif dalam rangkaian proses partisipasi dari tahap pengambilan keputusan hingga tahap evaluasi dalam kegiatan pengelolaan desa wisata; (2) Jenis usaha wisata berhubungan signifikan dengan tingkat partisipasi anggota Pokdarwis dalam pengelolaan Desa Wisata Nglanggeran. Faktor umur, lama tinggal, tingkat pendidikan, dan jumlah keluarga tidak berhubungan signifikan dengan tingkat partisipasi anggota Pokdarwis Nglanggeran dalam pengelolaan Desa Wisata Nglanggeran. Penilaian terhadap layanan Pokdarwis, yaitu peran fasilitatif dan peran mendidik tidak berhubungan signifikan dengan tingkat partisipasi anggota Pokdarwis dalam kegiatan pengelolaan Desa Wisata Nglanggeran; dan (3) Tingkat partisipasi berhubungan signifikan dengan perubahan kesejahteraan dalam hal tingkat pendapatan, kondisi lingkungan, dan kondisi sosial. Perubahan tingkat pendapatan berupa meningkatnya tingkat pendapatan, terpenuhinya kebutuhan sehari-hari serta sebagian pendapatan bisa membeli kebutuhan tambahan dan untuk ditabung, tingkat pengangguran berkurang karena terbukanya lapangan pekerjaan dari sektor wisata, berkurangnya penduduk desa yang merantau ke luar daerah dan memilih untuk tetap di desa untuk mengembangkan desanya sendiri. Perubahan kondisi lingkungan berupa peningkatan kebersihan lingkungan, lingkungan lebih tertata dan lebih asri setelah adanya pengelolaan desa wisata, serta sudah diaturnya kegiatan penebangan dan pengambilan kayu khususnya di kawasan hutan lindung. Perubahan kondisi sosial berupa peningkatan kepedulian antar masyarakat desa, meningkatnya kepercayaan diri anggota Pokdarwis untuk berinteraksi dengan wisatawan, perilaku tolong-menolong yang meningkat baik individu maupun yang dikoordinasi oleh Pokdarwis, serta upaya untuk mempertahankan budaya-budaya lokal yang diperkenalkan kepada wisatawan sehingga kebudayaan Desa Nglanggeran lebih dikenal oleh khalayak luas, sekaligus dapat menjadi nilai tambah ataupun sumber penghasilan Pokdarwis Nglanggeran. 


\section{Saran}

Berdasarkan hasil penelitian, ada beberapa hal yang dapat dijadikan saran dan masukan sebagai bahan pertimbangan: (1) Anggota Pokdarwis lebih terlibat aktif dalam semua tahapan partisipasi, terlebih dalam tahap evaluasi anggota Pokdarwis diharapkan lebih berani untuk memberikan pendapat, saran serta memberi kritik atau penilaian terkait pengelolaan Desa Wisata Nglanggeran. Perlu juga disediakannya kotak saran, agar anggota Pokdarwis yang enggan menyatakan pendapat secara langsung dapat memberikan saran atau masukan juga dan menjadi sarana pengunjung untuk memberi penilaian terkait pelayanan yang diberikan oleh Pokdarwis agar pengelolaan Desa Wisata Nglanggeran dapat ditingkatkan ke arah yang lebih baik ke depannya; (2) Diperlukan adanya pembinaan secara rutin yang dikoordinir oleh pengurus Pokdarwis Nglanggeran, agar setiap jenis usaha wisata dalam kegiatan pengelolaan Desa Wisata Nglanggeran untuk meningkatkan kapasitas masyarakat sehingga anggota Pokdarwis dapat menjalankan tugasnya dengan baik dan maksimal; dan (3) Pihak pemerintah desa sebaiknya melakukan monitoring dan mengawal secara rutin kegiatan pengelolaan Desa Wisata Nglanggeran, tidak hanya saat tertentu saja seperti sloso kliwon dan melakukan pendekatan untuk mengajak masyarakat Desa Nglanggeran agar mau ikut terlibat dalam pelaksanaan kegiatan pengelolaan Desa Wisata Nglanggeran.

\section{DAFTAR PUSTAKA}

[BPS] Badan Pusat Statistik. 2015. Indikator Kesejahteraan Rakyat. Tersedia pada:https://www.bps.go.id/publication/201511/ 10/9b1a211623201b8577993639/indikatorkesejahteraan-rakyat-2015.html

Kushandajani. 2015. Implikasi UU Nomor 6 Tahun 2014 tentang Desa terhadap Kewenangan Desa. Jurnal Y ustisia. [Internet]. [Diunduh 20 Januari 2020]: 4(2): 369-396. Tersedia pada: https://jurnal.uns.ac.id/yustisia/article/view/ 8656 Nasdian FT. 2014. Pengembangan Masyarakat. Jakarta (ID): Yayasan Pustaka Obor Indonesia. Undang-undang Republik Indonesia Nomor 06 Tahun 2014 Tentang Desa. Jakarta (ID): Sekretariat Negara

Undang-undang Republik Indonesia Nomor 10 Tahun 2009 Tentang Kepariwisataan. Jakarta (ID): Sekretariat Negara

Undang-undang Republik Indonesia Nomor 11 Tahun 2009 pasal 1 dan 2 tentang Kesejahteraan Sosial, Jakarta(ID): Sekretariat Negara

Uphoff N, Cohen J, dan Goldsmith, A. Rural Development Committee: Feasibility and Application of Rural Development Participation: A. State-of-the-Arth Paper. New York: Cornell University. 